\title{
ТЕОРЕТИЧЕСКИЕ ОСНОВЫ ФОРМИРОВАНИЯ КОНЦЕПЦИЙ АДМИНИСТРАТИВНОГО ДОГОВОРА В РОССИЙСКОЙ ФЕДЕРАЦИИ
}

\begin{abstract}
Аннотация: Договор как средство способное отражать самостоятельные волеизъявления участников согламений в основном характерен для гражданско-правового регулирования, для субъектов независимых друг от друга в своих полномочиях и интересах. Однако, договор в последнее время, также выступает регулятором многих публичных отраслей права и совершенно заслуженно занимает в них своё место, отчего в сфере управления актуализировалась проблема и категория «административных договоров».B статье приводится теоретическое обоснование административного договора как возможной и применимой административно-правовой формы. Рассматриваются вопросы теории и практики, регулируемые административным договором. Отражены мнения отечественных исследователей по проблемам административных договоров и общественные отношения, предлагаемые к урегулированию и основанные на правовой природе этого явления. Рассматриваются и представляются перспективные направления развития административных договоров. Предмет административного права и его задачи побуждают сделать вывод о внедрении этой формы как средства регулирования общественных отношений соответствующим законом в виде моделей договоров. Статья будет полезной для исследователей, занимающихся проблемами административного права: студентов, аспирантов, преподавателей.
\end{abstract}

Abstract: A contract serves as means of reflecting independent expressions of will of parties to treaties, and it is mostly typical for civil law regulation and for the subjects, which have independent competences and interests. However, lately contractual regulation is used in public relations, and the issue of the category of "administrative contracts" became topical. The article provides theoretical substantiation of an administrative contract as an acceptable and applicable administrative legal form. The article reflects the opinions of Russian scholars on the issues of administrative contracts and social relations subject to their regulation based on their legal nature. The author evaluates the perspectives of development of administrative contracts. The object of administrative law and its goals require the conclusion that a contractual form should be introduced as means for the regulation of social relations. The article shall be useful for researchers in the sphere of administrative law, students, postgraduate students, lecturers. Ключевые слова: административно-правовая форма, административный договор, публичное управление, правовая природа, модели административного договора, юридические свойства, нормативный договор, административное право, наука, проблемы права

Keywords: administrative legal form, administrative contract, public management, legal nature, model s of administrative contract, legal characteristics, normative contract, administrative law, scientific problems.

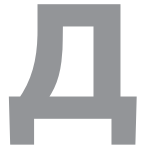

оговор, как основание административных правоотношений и сфера научного интереса, возник в мире ещё полтора столетия назад, в России этот интерес проявлялся в 20-х, $60-x, 90-х$ годах в 20 века. В последние 15 лет и теперь, в современном российском обществе, для него наступает пора наибольшего благоприятствования. Пожалуй, больше всего поводов для рассуждений исследователей о природе таких отношений даёт деятельность органов исполнительной власти. Отношения новой для российской действительности юридической природы возникли в связи с формированием цели организованного общества, расширением направлений и изменением характера деятельности органов государственного управления и способом раскрытия новых правовых форм и перспектив развития административного права.

За это время государство и право переориентировались на новые экономические формы и пути развития общества, обеспечивая свободу и поддержку в их развитии. Многие принимаемые законы и нормативно-правовые акты, имели главным смыслом решение этих задач. 
DOI: 10.7256/1811-9018.2013.12.10267

При цитировании этой статьи сноска на dоі обязательна

\section{Право и политика $12(167) \cdot 2013$}

Развитие процессов экономики, несомненно, влияет на содержание правовой базы общества ${ }^{1}$, способной в современных условиях разнообразить методы и формы официального управления посредством привлечения возможностей общественности к взаимовыгодному сотрудничеству с органами исполнительной власти.

Этому способствовал ряд факторов. Начиная с преобразования отношений собственности, отмены планового распределения, стремления привести в порядок систему административных предписаний, и заканчивая договорным регулированием административных отношений, складывающихся по горизонтали, дополняя их далеко еще не исчерпанным арсеналом и гарантиями административного ресурса.

Следует учитывать, что нынешние правовые и общественные изменения являются результатом процесса демократизации общества. Демократия предполагает наличие развитых институтов власти, в которых гражданская позиция способна оказывать непосредственное воздействие на общественные отношения, в том числе, и на процессы управления².

Одним из способов в достижении такого положения и может быть договор, рассматриваемый в качестве средства реализации права или способа координации принимаемых властями решений, предполагая участие в них невластных субъектов.

Модель, способная отражать равнозначные волеизъявления участников соглашений, характерна для гражданско-правового регулирования, для субъектов независимых друг от друга в своих полномочиях и интересах. В частности, в межгосударственных отношениях, в международном праве. Основное для таких отношений средство, - договор - проникает и в публичные отрасли права ${ }^{3}$. Поэтому в сфере управления актуализировалась проблема и категория «административных договоров».

Отправной точкой юридической конструкции, ставшей предметом настоящего исследования, как и для каждой правовой дисциплины является Конституция РФ. Разумеется, это не единственный её элемент, но все частности изучаемой проблемы, так или иначе,

\footnotetext{
${ }^{1}$ Розенфельд В.Г., Старилов Ю.Н. Проблемы современной теории административного договора // Правоведение. - 1996. - № 4. C.47-63.

2 Ямпольская Ц.А. О теории административного договора // Советское государство и право. - 1966. - № 10. - С. 134.

${ }^{3}$ Коречкий А.Д. Теоретико-правовые основы учения о договоре / Отв. ред. заслуженный деятель науки РФ, докт. юрид. наук, проф., акад. РАЕН П.П. Баранов. - С-Пб.: Издательство «Юридический центр Пресс», - 2001. - С. 130.
}

восходят к конституционным принципам, обеспечивая её соответствие заданным стандартам социального государства, гарантиям прав и свобод.

В самом общем виде административный договор представляет собою способ правового регулирования общественных отношений с участием субъектов административного права, между которыми существуют, как горизонтальные, так и вертикальные связи, открывающие область действия административных норм для договорных, диспозитивных начал. Административный договор является составной частью системы договоров и выделен именно с целью поиска путей повышения эффективности управленческой деятельности, направленной на удовлетворение общественно значимых интересов.

Отмечая экономические предпосылки растущего интереса к договорам, необходимо заметить, что такая тенденция возникала и ранее в разных экономически развитых регионах. Исторически такой экономический процесс выступал первоосновой для признания договоров в качестве правовой формы управления либо формы закрепления правовой позиции общества. Это доказывает наличие договорной теории государства и права, то есть договор как форма организации общества - это стабильная правовая и теоретическая категория. В современном капиталистическом обществе задачи, решаемые частным правом, заставили власть поновому оценить возможности договоров. Происходит процесс возвращения к истокам с одним дополнением, для договорного управления общество должно быть свободно в правах и экономически развито. Причины затруднения изучения договорного управления прямо пропорциональны: это слабо развитые экономические отношения, где методология императивного государственного властвования может обходиться без дополнительных (договорных) ресурсов. Но и в таких условиях договорные элементы имеются.

Интерес к теории и практике административных договоров объясняется возможностью эффективного привлечения к обеспечению интересов договаривающихся сторон административного ресурса. Это экономически нейтральная категория административного права, способствующая эффективному согласованию позиций договаривающихся сторон.

В сфере административной деятельности можно выделить договоры о выполнении органами исполнительной власти, а также их подразделениями властных полномочий, трансформированных в публичные услуги, осуществляемые по требованию заинтересованной стороны. Примером тут могут послужить услуги 
публичных библиотек, муниципального транспорта, изготовления удостоверенных органами власти документов, экспертиз, варианты партнёрства, услуги по реализации требований закона и т.д.

Существуют правительственные программы и инициативы (к примеру, по профилактике совершения правонарушений и травматизма среди участников дорожного движения, реализуемые совместно со спортивными обществами, клубами), в которых особое внимание уделяется комплексу мероприятий, осуществляемых при встречном, характерном скорее для цивильных правоотношений, волеизъявлении субъектов и т.п.

Особое место среди административных договоров, объяснимое спецификой их организационно-распорядительного предмета, занимают договоры по передаче полномочий. Их особенность в том, что они существуют на всех уровнях власти. Отдельный интерес представляет перевод государственных учреждений в статус «госкорпораций» акционерных обществ и то, каким образом будет осуществляться эта работа, как на эти, по сути, новые организационно-правовые формы будут оказывать влияние законы, разработанные для государственных и муниципальных предприятий.

На первый взгляд, они оставляют впечатление, что государство, допуская договорную форму управления, самоустраняется от выполнения некоторых своих обязанностей, уступая противной стороне их выполнение.

Объяснять это можно веяниями демократии, спецификой развития современных экономических отношений, и особыми качествами управления, проявляющимися в среде частного предпринимательства. Это одна из точек зрения.

И здесь уместно уточнить, что в целом, роль участия государства в управлении социально значимыми процессами не сокращается, а остаётся прежней. Всё дело в том, что публичное присутствие государства в сфере частных правоотношений переходит на новый уровень. Имеет смысл подчеркнуть, что актуальность проблемы административного договора в настоящее время обусловлена не только развитием договорных начал в публично-правовых отношениях и развитием административного права, но и тенденцией к возрастанию роли публичного права в регулировании общественных отношений. Это один из первых шагов государства по реформированию собственной распорядительской системы, в перспективе способной обеспечивать прогресс и инновации в управлении общественными институтами.

В формирующихся административно-договорных моделях отчётливо прослеживается самостоятельный предмет. Административно-договорные отношения можно охарактеризовать и как специфическое гарантирование декларативных принципов ${ }^{4}$, и как особое направление решения поставленных перед органами управления задач, и как отношения, в которых важное место занимают взаимодействующие равнозначные для общества права граждан и органов исполнительной власти в области оказания публичных услуг.

Основные проблемы, требующие осмысления теоретической сущности административного договора и привлекающие внимание, заключаются в том, что это новое правовое явление сопровождается выявлением пробелов и множеством организационных неувязок. Среди таковых следует назвать недостаточность существующих правовых средств, сложность установления правовой природы выполняемых на основании договора действий, проблемы поиска критериев определения его места в системе правовых средств, неопределенность сферы его субъектного состава.

Административно-правовой договор самостоятельно представлен в системе публично-правовых договоров. Во многих странах (Франция, Италия, Швейцария) эти понятия различают, подчеркивая, что административно-правовой договор является только частью общего понятия - «публично-правовой договор». Этим понятием охватывают все договоры, заключаемые органами государственной власти и местного самоуправления. В Германии эти понятия совпадают - административный договор является публично-правовым аналогом гражданско-правового договора, имеющегося в частном пра$\mathrm{Be}^{5}$. Следует согласиться с тем, что область применения категории публично-правового договора намного шире, области действия категории административно-правового договора, о чем, несомненно, свидетельствует хорошо различимый набор их признаков.

Под публично-правовым договором принято понимать волевое соглашение не менее двух субъектов публичного права, заключенное на основании норм публичного права в общественных (общегосударственных) интересах, правовой режим которого содержит элементы, выходящие за рамки частного (гражданского) права ${ }^{6}$.

\footnotetext{
${ }^{4}$ Тихомиров Ю.А. Договор как регулятор общественных отношений // Правоведение. - 1990. - № 5. - С. 29.

${ }_{5}^{5}$ Мицкевич Л.А. Основы административного права Германии: Монография. - Красноярск: КрасГУ, Издательство «Универс», 2002. - C. 92.

${ }^{6}$ Демин А.В. Общие вопросы теории административного договора / Краснояр. гос. ун-т. - Красноярск, - 1998. - С. 16.
} 
DOI: $10.7256 / 1811-9018.2013 .12 .10267$

При цитировании этой статьи сноска на dоі обязательна

\section{Право и политика $12(167) \cdot 2013$}

Под административным же договором, в частности, А.В. Дёмин предлагает понимать управленческое соглашение не менее двух субъектов административного права, заключённое на основе норм административного права в публичных целях опосредования горизонтальных (координационных) управленческих отношений, правовой режим которых содержит административно-правовые элементы, выходящие за рамки частного права7.

Д.Н. Бахрах считает, что административный договор - это основанный на административно-правовых нормах и выработанный в публичных интересах в результате добровольного согласования воли двух (либо более) субъектов административного права, одним из которых всегда выступает субъект административной власти, многосторонний акт, устанавливающий (прекращающий, изменяющий) взаимные права и обязанности его участников ${ }^{8}$.

А.Д. Корецкий, рассматривая природу административных договоров, обобщенного понятия не приводит 9 Не делают этого и в коллективе авторов в составе А.П. Алехина, А.А. Кармолицкого, Ю.М. Козлова ${ }^{10}$.

В автореферате А.С. Ротенберга определения административного договора не даётся, но там выделены признаки по которым:

1. административный договор представляет собой управленческое решение, принятое для достижения конкретных целей посредством реализации соответствующих управленческих функций;

2. административный договор выражает согласованную волю субъектов административного права, как минимум один из которых при заключении договора реализует полномочие исполнительной власти;

3. административный договор представляет собой правовой акт управления, ибо его совершение влечёт определённые правовые последствия ${ }^{11}$.

С.В. Курчевская определяет административный договор следующим образом: «Административный

\footnotetext{
${ }^{7}$ Демин А.В. Общие вопросы теории административного договора / Краснояр. гос. ун-т. - Красноярск, - 1998. - С. 16.

${ }^{8}$ Бахрах Д.Н. Административное право России. Учебник для вузов. - М.: «Издательская группа НОРМА-ИНФРА-М», - 2000. - С. 185.

${ }^{9}$ Кореикий А.Д. Теоретико-правовые основы учения о договоре. - С-Пб.: Издательство «Юридический центр Пресс», - 2001. C. 130-136.

${ }^{10}$ Административное право: Учебник / Под ред. Ю.М. Козлова, Л.Л. Попова. - М.: «Юристъ», - 2001. - С. 261-268.

${ }^{11}$ Ротенберг А.С. Административный договор /: автореф. дис. на соискание учёной степени канд. юрид. наук: 12.00.14. - Ростов н/Д. - 2006. - С. 14-15.
}

договор - соглашение двух или более субъектов административного права, как минимум один из которых обладает государственно-властными полномочиями и реализует в договоре управленческие функции, устанавливающее (прекращающее, изменяющее) административные права и обязанности, направленное на удовлетворение общественно значимых интересов и регулируемое административно-правовыми нормами, а также общими положениями о договоре, установленными гражданским законодательством в той части, в которой они не противоречат публичноправовой природе данного соглашения» ${ }^{12}$. При этом С.В. Курчевская ставит задачу отграничить административный договор от гражданско-правовых, а также прочих публично-правовых договоров ${ }^{13}$. Приведенное мнение, в совокупности с определением, данным Д.Н. Бахрахом и союзе с признаками, выделенными А.С. Ротенбергом, заслуживают особенного внимания. В последнем определении содержится теоретический подход, с позиций которого просматривается аналогия закона и административного договора воспринятая правом ФРГ и описанная научным руководителем С.В. Курчевской, - Ю.Н. Стариловым ${ }^{14}$.

Приведённые вначале краткие замечания о моделях административных договоров были привлечены с целью выделения особенности административных отношений. Но в учёной среде, несмотря на многообразие суждений, преобладает мнение, что административный договор представляет промежуточную категорию между договором и административным актом. Рассматривая административный договор как систему, мы проводим его исследование в комплексе правовых форм, где отмечаем существование проблем самих административно-правовых форм. Например, нет закона посвящённого регулированию правового акта управления, одному из основных юридических понятий и средств на котором базируется вся административная отрасль. Что небезосновательно. Это прослеживается, как в определениях отечественных учёных, так и в предлагаемых некоторыми французскими и немецкими

\footnotetext{
${ }^{12}$ Курчевская С.В. Административный договор: формирование современной теории и основные проблемы /: автореф. дис. на соискание учёной степени канд. юрид. наук: 12.00.14. - Воронеж, -2002 . - C. 17.

${ }^{13}$ Курчевская С.В. Административный договор: формирование современной теории и основные проблемы /: автореф. дис. на соискание учёной степени канд. юрид. наук: 12.00.14. - Воронеж, - 2002. - C. 16.

${ }^{14}$ Старилов Ю.Н. Административный договор: опыт законодательного регулирования в Германии // Государство и право. -1996. - № 12. - C. 44.
} 
исследователями признаках и критериях определения местоположения административных договоров, выводящих таковые за пределы рамок частного права.

Как уже было отмечено, термин договор не свойственен административному праву и заимствован из таких отраслей, где отношения между сторонами складываются на принципах регулирования, независящих от отраслевой принадлежности соглашений. К таким принципам относятся: диспозитивность; автономия воли договаривающихся сторон; формально-юридическое равноправие контрагентов; эквивалентный характер договора; ответственность сторон и т.п ${ }^{15}$.

Напротив, В.В. Иванов и А.Д. Корецкий рассматривают договор как общеправовую категорию, по отношению к конкретным правовым дисциплинам ${ }^{16}$, то есть не принадлежащую изначально к какой-либо отрасли права. Признавая такое положение в целом, имеет смысл не согласиться с тем, что предметом административных договоров могут становиться отношения, выходящие за рамки частного права. Поскольку они таковыми должны признаваться изначально. То есть не следует проверять по договор по Гражданскому кодексу Российской Федерации (далее - ГК РФ), для того чтобы установить его в качестве гражданско-правового. Существуют примеры, когда административными признавались как отношения указанные в ГК РФ, так и отношения, не предусмотренные ГК РФ. Тут нужно рассматривать природу самих отношений, чей статус на них распространяется, кому принадлежит имущество, на праве какой собственности.

Безусловно, административно-правовые элементы не вписываются в рамки частного права, но их наличие обусловлено специфическим и многогранным предметом административных договоров, не относящимся к частному праву, прежде всего, задачами, стоящими перед административными органами. Поэтому вернее говорить об административных договорах, как о разновидности общеотраслевых договоров, напротив, осложненных элементом административного права. Сама юридическая новизна этой темы логически предпосылает актуальность природы таких соглашений, особенность их характера, специфику горизонтальности этих отношений, особенности их условий, отличающие от

${ }^{15}$ Демин А.В. Общие вопросы теории административного договора / Краснояр. гос. ун-т. Красноярск, - 1998. - С. 14.

${ }^{16}$ Иванов В.В. Общая теория договоров. - М.: «Юристъ», - 2006. - С. 238. Кореикий А.Д. Теоретико-правовые основы учения о договоре. - С-Пб.: Издательство «Юридический центр Пресс», $-2001 .-$ C. 211. частноправовых договоров, и прочее. Приведенный пример касается тех административно-правовых договоров, которые относятся к оказанию публичных услуг и им подобных. На самом деле административному договору отведена роль регулировать больший объём отношений и поэтому некоторые критерии могут не совпадать.

В связи с этим интересно одно обстоятельство. Элемент административного права, который предлагается в качестве идентификатора административных договоров в общей системе договоров, уже сам по себе охватывается вышеуказанным определением (как соглашение, заключенное на основе норм административного права), и должен поглощаться им. Появляется вопрос: С какой целью административно-правовой режим привносится в рамки частного права? Скорее всего, желание совместить оба юридически значимых качества, обусловлено - либо отношением ко всем договорам как к главному частноправовому регулятору, либо желанием подчеркнуть, что административный договор способен регулировать и частноправовые отношения. Помещая их в рамки административного режима, устанавливаются, тем самым, управленческие отношения, смысл которых сводится не к получению прибыли, а к достижению иной, значимой для всего общества пользы.

Думается, у таких договоров есть определённые шансы на существование, именно при условии, что не каждый административный договор по своему предмету и содержанию преследует цель регулирования частноправовых отношений.

Признание роли гражданского права в административно-договорных отношениях как существенной, можно считать оправданным лишь с оговоркой, что гражданско-правовые договоры имеют большее длительное теоретическое и историческое развитие, отчего, вполне логично обращение за юридическими аналогиями именно в эту отрасль.

Представляется, что административный акт, безусловно, является основной - оперативной, но не единственной административно-правовой формой. C момента укоренения в системе правовых форм, договор становится самостоятельным регулятором общественных отношений (договоры на передачу полномочий, по оказанию государственных услуг). По сути, его положение равнозначно положению административного акта. Более того, должностное лицо, при исполнении служебных обязанностей, исходя из принципа целесообразности, может принять решение о долгосрочном договорном регулировании, как альтернативу применению административно-властного решения (договоры об обмене информацией). 
DOI: $10.7256 / 1811-9018.2013 .12 .10267$

При цитировании этой статьи сноска на ооі обязательна

\section{Право и политика $12(167) \cdot 2013$}

Большую роль в становлении и распространении административного договора играет его договорное начало, в частности, те части соглашения, которые посвящены взаимным правам, которые и делают административный договор «живым обязательством». Содержание этих частей должно соответствовать целям, для достижения которых заключается договор. Несомненно, в случае возникновения ситуации, требующей скорейшего разрешения, необходимо использовать императивные административные рычаги воздействия на общество. Именно в этом случае административное право получает новый смысл именно как «буферная отрасль», и не только относительно уголовного права, но и относительно гарантирования постоянной готовности к переговорам равноправных сторон, их конструктивному диалогу. Поэтому органы власти должны быть способны предложить своим контрагентам административно-договорный механизм исполнения закона, основанный на административном ресурсе во всём его проявлении применительно к обеспечению координации позиций договаривающихся сторон. Эти возможности государства в свою очередь должны привлекать потенциальных субъектов таких договоров к сотрудничеству. Это качество ставит административный договор на один уровень с административно-правовым актом. Именно как правовую форму, направленную на решение конкретных задач, имеющую свой специфический предмет регулирования, а потому законно занимающую своё место в системе общего договорного регулирования. Развитие административных договоров может привести к созидательной конкуренции, как среди административно-правовых форм, так и среди договорных форм.

Договор, как общеправовая категория, традиционно определяется через волевое соглашение двух или более субъектов права, влекущее установление, изменение или прекращение определённых правоотношений.

Анализ публичных договоров иных отраслей показывает, что предметом международного права всецело являются публичные международные договоры, от которых следует в первую очередь воспринять саму практическую возможность использования публичных договоров. Имеет смысл обратить внимание на то, что важной задачей, решаемой административными договорами, является необходимость управления внутригосударственными интересами и продвижение их в обществе. Из этого следует, что полномочия органов власти, складывающиеся из прав и обязанностей, должны иметь своё выражение не только как право органа на применение правовой формы в необходимом административном случае, но и как обязанность применить таковую. Кроме того, органы должны иметь само «право на право». Говоря о праве следует помнить, что право органа власти одновременно является его же обязанностью, но теория административного договора расширяет внутреннее полномочие органа власти действовать в ином, волевом ключе для достижения цели управления. В виду того, что договорённость менее формализована в отличие от административных процедур в их классическом представлении, появляется новая категория - право на диспозицию управленца самому определить вариант правового воздействия. Этому способствует незавершенность системы административных договоров, неопределенность их классификации, а также особая самостоятельность их субъектов.

Из сказанного можно сделать вывод о специфике административных договоров - «политических» решений. В своё время А.И. Елистратов говорил «о целесообразности использования обычных средств частно-хозяйственного оборота вместо принудительного нажима» ${ }^{17}$. Эти договоры не обязательны и применяются как альтернатива нормативному правовому акту. В них содержится стремление государственно-властных субъектов распространить своё распорядительское влияние на неурегулированные отношения или на неподвластных субъектов. В таких отношениях, в отдельных случаях, не обладающие властью субъекты могут гарантировать такое решение. Пример надлежащего соглашения описал Ю. Вольдман в комментарии к статье 26 Закона «О рекламе»: антимонопольное управление и ассоциация работников печати Рязанской области заключили соглашение о соблюдении правил и обычаев рекламной практики. Соглашение предусматривает обязательства антимонопольного управления и ассоциации работников печати доводить до средств массовой информации результаты мониторинга рекламной деятельности, обеспечивать их нормативно-методическими материалами, осуществлять обучение и консультации работников рекламных отделов и т.п. В свою очередь средства массовой информации принимают обязательства по предупреждению появления в их изданиях или эфире ненадлежащей рекламы ${ }^{18}$.

\footnotetext{
${ }^{17}$ Елистратов А.И. Очерк административного права. - М.: «Госиздат», - 1922. - С. 95. (Цит. по Новосёлову В.И. «К вопросу об административных договорах») // Известия вузов. Правоведение. - 1969. - № 3. - C. 41.

${ }^{18}$ Вольдман Ю. Комментарий закона РФ «О рекламе» // Хозяйство и право. - 1997. - № 12. - С. 4-5.
} 
А вот в отношении индивидуальных административных соглашений между субъектами административного права (к примеру, автолюбителем и ГИБДД по поводу соблюдения законодательства о безопасности дорожного движения), необходимо иметь дифференцированный подход. Трудность заключается в том, что надлежащее соблюдение данного соглашения будет сложно подтвердить, во-первых, не все правонарушения фиксируются; во-вторых, нарушение соглашения будет выявляться в самих случаях правонарушений, что не будет соответствовать принципу целесообразности ${ }^{19}$, хотя заключение подобных индивидуальных соглашений в области налогового или финансового права вполне может привести к ощутимым управленческим результатам.

Существуют также административные договоры о передаче полномочий на разных уровнях исполнительной власти: на федеральном и региональном (их можно назвать «конституционными»). Эти договоры обладают высокой степенью нормативности и затрагивают интересы множества субъектов, они не «страдают» засильем «микронорм» ${ }^{20}$. По мнению А.В. Дёмина они подлежат обязательному опубликованию в официальных изданиях ${ }^{21}$.

Особое значение представляют административные договоры-обращения. Это договоры, предметом которых является обязанность управленца принять решение. В такой форме могут быть исполнены публичные услуги.

Общими свойствами, которыми обладают административные договоры, являются правотворчество (нормативные договоры) $)^{22}$, правоприменение (индивидуальные договоры $)^{23}$, координационные и субординационные связи. Такие договоры можно назвать организационными.

Все они отличаются уровнем управленческого воздействия, правовой природой и направлением связей, характеризующих, инициаторов процесса, их отношения с другими органами власти, в том числе и нижестоящими, или невластными субъектами права.

\footnotetext{
${ }^{19}$ Демин А.В. «Контракты в сфере оперативно-розыскной деятельности» // Российская юстиция. - 1997. - № 6.

${ }^{20}$ Кашанина Т.В. Индивидуальное регулирование в правовой сфере // Советское государство и право. - 1992. - № 2. - С. 124.

${ }^{21}$ Демин А.В. Общие вопросы теории административного договора. - Красноярск: «Краснояр. гос. ун-т», - 1998. - С. 93.

${ }^{22}$ Иванов В.В. Общая теория договоров. - М.: «Юристъ», - 2006. - C. 238.

${ }^{23}$ Коренев А.П., Абдурахманов А.А. Административные договоры: понятие и виды // Журнал российского права. - 1998. - № 7. - С. 86.
}

Во всех этих случаях договор является окончательной формой волеизъявления властного органа.

Все приведенные ситуации обладают характерными признаками и специфически влияют на восприятие природы самого договора и на его осмысление. Это весьма затрудняет определение понятия «административного договора», провоцируя искушение дать каждому из них своё уникальное толкование.

Преодолеть указанную проблему поможет следующее рассуждение. Размышляя о природе административного договора, необходимо помнить о том, что юридически он представляет собой внешнее выражение деятельности административных органов. По мнению Ю.Н. Старилова на проблему административного договора, «следует смотреть не только с точки зрения материальных административно-правовых норм, устанавливающих статутные положения (участники, права, обязанности, ответственность, административно-правовой режим исполнения), но и с позиций административнопроцессуального права. Ведь традиционно мы говорим о таком виде административного процесса, входящем в его структуру, как административно-договорный процесс, то есть административный договор - это одно из административно-процессуальных производств. Это - так называемый «позитивный административный процесс», который, конечно, имеет свою материальную часть» $2^{24}$. Следовательно, внешняя деятельность органа власти, должна, если и не обязательно регулироваться посредством заключения административно-правовых договоров, то должна, хотя бы создавать предпосылки для такой перспективы управленческих отношений.

Это как раз и предопределяет необходимость комплексного подхода в изучении административно-правовых форм управления. Существует необходимость принятия законов посвящённых административным актам и административным договорам, а также включению соответствующих процессуальных глав в будущий закон, регламентирующий административный процесс Российской Федерации. Действующий в настоящее время КоАП РФ регулирует материальную и юрисдикционную части вопросов касающихся нарушения административного закона. При этом огромный объём повседневной административной деятельности субъектов административного права остаётся разрозненным, и урегулированным излишне конкретизированными, а потому проблемными в своём применении законами, инструкциями и приказами.

\footnotetext{
${ }^{24}$ Старилов Ю.Н. Административный договор: опыт законодательного регулирования в Германии // Государство и право. - 1996. - № 12. - C. 42-43.
} 


\section{Право и политика 12 (167) • 2013}

К примеру, в Германии, административный договор и административный акт названы в параграфе 9 Административно-процессуального закона ФРГ в качестве процессуальных актов ${ }^{25}$.

Есть основания полагать, что определять природу административного договора следует, опираясь на его процессуальное значение, способствуя отражению в дефиниции, наряду с источником, и особенности определяемых правоотношений. Предлагаемую идею можно принять за основу и в будущем закрепить в соответствующем законе. Административный договор - это договор сторон, посредством которого возникает, изменяется либо прекращается правовое отношение в области действия административного права.

Особенности отдельных административных договоров должны регулироваться моделями договорных отношений. Эти модели дополнят статус административного договора по характеру управления, предмету, виду, его возмездности, уровню субъектов в нём участвующих. Административный договор по своей природе предполагается безвозмездным для стороны управления. Взимаемая оплата за услуги выполняемые органами управления носит дополнительный характер. У какой-либо стороны должен отсутствовать первоочередной коммерческий интерес, извлекаемый из этого соглашения, так как в ином случае оно стало бы противоречить целям своего заключения. Интересен вопрос о сторонах соглашения. В зависимости от типа договора стороной может стать любой субъект административного права. В отдельных случаях для целей договора должен быть произведён качественный ценз этих субъектов. Субъект по своим возможностям должен быть способен обеспечить достижение органами власти целей ставящихся при заключении договора, и за которым у органов власти сложится реальная практика надзора за ходом исполнения обязательства. Выделяя особенности каждого их них, они обусловят административный режим их реализации. Такие модели могут быть выстроены в отдельные главы соответствующего закона об административном договоре, наподобие гражданского кодекса.

В заключение необходимо отметить, что понятие административного договора не определено отечественным законодательством, но, в силу своего существа, оно обладает признаками, развитие и определение которых подлежит дальнейшему теоретическому, прак-

${ }^{25}$ Старилов Ю.Н. Административный договор: опыт законодательного регулирования в Германии // Государство и право. -1996. - № 12 . - C. 47. тическому изучению и сравнению. Акцентирование внимания на развитии процессуальных возможностей договорной формы и развитии процессуальной составляющей всей системы административного договора, откроет новые аспекты его содержания, субъектного состава, правового режима. Теория и практика нуждаются в выделении, отраженных в соответствующем определении, признаков административного договора, независимых как от пережитков традиций, так и от конъюнктурных метаний. Представляется, что этим критериям в наибольшей степени соответствует определение административного договора, как договора сторон, посредством которого возникает, изменяется либо прекращается административно-правовое отношение. Надлежит также установить процессуальные критерии признаков административного договора и разработать разделы, посвященные определённым моделям административного договора.

\section{Библиография:}

1. Розенфельд В.Г., Старилов Ю.Н. Проблемы современной теории административного договора // Правоведение. - 1996. - № 4. - С.47-63.

2. Ямпольская Ц.А. О теории административного договора // Советское государство и право. - 1966. - № 10. - С. 134.

3. Корецкий А.Д. Теоретико-правовые основы учения о договоре / Отв. ред. заслуженный деятель науки РФ, докт. юрид. наук, проф., акад. РАЕН П.П. Баранов. - С-Пб.: Издательство «Юридический центр Пресс», - 2001. - С. 130.

4. Тихомиров Ю.А. Договор как регулятор общественных отношений // Правоведение. - 1990. №5. - C. 29.

5. Мицкевич Л.А. Основы административного права Германии: Монография. - Красноярск: КрасГУ, Издательство «Универс», - 2002. - С. 92.

6. Демин А.В. Общие вопросы теории административного договора / Краснояр. гос. ун-т. Красноярск, - 1998. - С. 16.

7. Бахрах Д.Н. Административное право России. Учебник для вузов. - М.: «Издательская группа НОРМА-ИНФРА-М», - 2000. - С. 185.

8. Корецкий А.Д. Теоретико-правовые основы учения о договоре. - С-Пб.: Издательство «Юридический центр Пресс», - 2001. - С. 130-136.

9. Козлова Ю.М., Попов Л.Л. Административное право: Учебник - М.: «Юристъ», - 2001. - С. 261-268. 
10. Ротенберг А.С. Административный договор /: автореф. дис. на соискание учёной степени канд. юрид. наук: 12.00.14. - Ростов н/Д. - 2006. - С. 14-15.

11. Курчевская С.В. Административный договор: формирование современной теории и основные проблемы /: автореф. дис. на соискание учёной степени канд. юрид. наук: 12.00.14. - Воронеж, -2002. - С. 17.

12. Курчевская С.В. Административный договор: формирование современной теории и основные проблемы /: автореф. дис. на соискание учёной степени канд. юрид. наук: 12.00.14. - Воронеж, 2002. - C. 16.

13. Старилов Ю.Н. Административный договор: опыт законодательного регулирования в Германии // Государство и право. - 1996. - № 12. - С. 44.

14. Демин А.В. Общие вопросы теории административного договора / Краснояр. гос. ун-т. Красноярск, - 1998. - C. 14.

15. Иванов В.В. Общая теория договоров. - М.: «Юристъ», - 2006. - С. 238. Корецкий А.Д. Теоретико-правовые основы учения о договоре. С-Пб.: Издательство «Юридический центр Пресс», - 2001. - C. 211.

16. Елистратов А.И. Очерк административного права. - М.: «Госиздат», - 1922. - С. 95. (Цит. по Новосёлову В.И. «К вопросу об административных договорах») // Известия вузов. Правоведение. 1969. - № 3. - C. 41.

17. Вольдман Ю. Комментарий закона РФ «О рекламе» // Хозяйство и право. - 1997. - № 12. - С. 4-5.

18. Демин А.В. «Контракты в сфере оперативно-розыскной деятельности» // Российская юстиция. - 1997. - № 6.

19. Кашанина Т.В. Индивидуальное регулирование в правовой сфере // Советское государство и право. - 1992. - № 2. - С. 124.

20. Демин А.В. Общие вопросы теории административного договора. - Красноярск: «Краснояр. гос. ун-т», - 1998. - С. 93.

21. Иванов В.В. Общая теория договоров. - М.: «Юристъ», - 2006. - С. 238.

22. Коренев А.П., Абдурахманов А.А. Административные договоры: понятие и виды // Журнал российского права. - 1998. - № 7. - С. 86.

23. Старилов Ю.Н. Административный договор: опыт законодательного регулирования в Германии // Государство и право. - 1996. - № 12. - С. 42-43.

24. Старилов Ю.Н. Административный договор: опыт законодательного регулирования в Германии // Государство и право. - 1996. - № 12. - С. 47.
25. Цалиев А.М. Расширение роли субъектов Российской Федерации в государственной политике // NB: Вопросы права и политики.-2013.-3.-C. 21-94. URL: http://www.e-notabene.ru/lr/article_554.html

26. Бут С.С. Система административно-правовых средств противодействия коррупции в таможенных органах Российской Федерации // NB: Административное право и практика администрирования. - 2013. - 9. - С. 88-98. URL: http://www.enotabene.ru/al/article_10137.html

27. Аринин Е.А. Теоретические аспекты организационно-правового механизма налогообложения в Российской Федерации. // NB: Финансовое право и управление. - 2013. - 4. - C. 1-29. URL: http:// www.e-notabene.ru/flc/article_855.html

28. Васнецова А.С. Патриотическое воспитание граждан Российской Федерации в системе противодействия экстремистской и террористической деятельности:общефедеральные и региональные аспекты // NB: Национальная безопасность. - 2013. - 5. - C. 142-153. URL: http://www.e-notabene.ru/nb/ article_9517.html

\section{References (transliteration):}

1. Rozenfel'd V.G., Starilov Yu.N. Problemy sovremennoi teorii administrativnogo dogovora // Pravovedenie. 1996. - № 4. - S.47-63.

2. Yampol'skaya Ts.A. O teorii administrativnogo dogovora // Sovetskoe gosudarstvo i pravo. - 1966. - № 10. - S. 134.

3. Koretskii A.D. Teoretiko-pravovye osnovy ucheniya o dogovore / Otv. red. zasluzhennyi deyatel' nauki RF, dokt. yurid. nauk, prof., akad. RAEN P.P. Baranov. - S-Pb.: Izdatel'stvo «Yuridicheskii tsentr Press», -2001. - S. 130.

4. Tikhomirov Yu.A. Dogovor kak regulyator obshchestvennykh otnoshenii // Pravovedenie. - 1990. - №5. - S. 29.

5. Mitskevich L.A. Osnovy administrativnogo prava Germanii: Monografiya. - Krasnoyarsk: KrasGU, Izdatel'stvo «Univers», - 2002. - S. 92.

6. Demin A.V. Obshchie voprosy teorii administrativnogo dogovora / Krasnoyar. gos. un-t. - Krasnoyarsk, 1998. - S. 16.

7. Bakhrakh D.N. Administrativnoe pravo Rossii. Uchebnik dlya vuzov. - M.: «Izdatel'skaya gruppa NORMA-INFRA-M», - 2000. - S. 185.

8. Koretskii A.D. Teoretiko-pravovye osnovy ucheniya o dogovore. $-\mathrm{S}-\mathrm{Pb}$.: Izdatel'stvo «Yuridicheskii tsentr Press», - 2001. - S. 130-136. 
DOI: 10.7256/1811-9018.2013.12.10267

При цитировании этой статьи сноска на dоі обязательна

\section{Право и политика 12 (167) • 2013}

9. Kozlova Yu.M., Popov L.L. Administrativnoe pravo: Uchebnik - M.: «Yurist"», - 2001. - S. 261-268.

10. Rotenberg A.S. Administrativnyi dogovor /: avtoref. dis. na soiskanie uchenoi stepeni kand. yurid. nauk: 12.00.14. - Rostov n/D. - 2006. - S. 14-15.

11. Kurchevskaya S.V. Administrativnyi dogovor: formirovanie sovremennoi teorii i osnovnye problemy /: avtoref. dis. na soiskanie uchenoi stepeni kand. yurid. nauk: 12.00.14. - Voronezh, - 2002. - S. 17.

12. Kurchevskaya S.V. Administrativnyi dogovor: formirovanie sovremennoi teorii i osnovnye problemy /: avtoref. dis. na soiskanie uchenoi stepeni kand. yurid. nauk: 12.00.14. - Voronezh, - 2002. - S. 16.

13. Starilov Yu.N. Administrativnyi dogovor: opyt zakonodatel'nogo regulirovaniya v Germanii // Gosudarstvo i pravo. - 1996. - № 12. - S. 44.

14. Demin A.V. Obshchie voprosy teorii administrativnogo dogovora / Krasnoyar. gos. un-t. Krasnoyarsk, - 1998. - S. 14.

15. Ivanov V.V. Obshchaya teoriya dogovorov. - M.: «Yurist"»,- 2006. - S. 238. Koretskii A.D. Teoretikopravovye osnovy ucheniya o dogovore. - S-Pb.: Izdatel'stvo «Yuridicheskii tsentr Press», - 2001. - S. 211.

16. Elistratov A.I. Ocherk administrativnogo prava. - M.: «Gosizdat», - 1922. - S. 95. (Tsit. po Novoselovu V.I. «K voprosu ob administrativnykh dogovorakh») // Izvestiya vuzov. Pravovedenie. - 1969. - № 3. - S. 41.

17. Vol'dman Yu. Kommentarii zakona $\mathrm{RF}$ «O reklame» // Khozyaistvo i pravo. - 1997. - № 12. - S. 4-5.

18. Demin A.V. «Kontrakty v sfere operativno-rozysknoi deyatel'nosti» // Rossiiskaya yustitsiya. - 1997. - № 6.

19. Kashanina T.V. Individual'noe regulirovanie v pravovoi sfere // Sovetskoe gosudarstvo i pravo. - 1992. - № 2. - S. 124.
20. Demin A.V. Obshchie voprosy teorii administrativnogo dogovora. - Krasnoyarsk: «Krasnoyar. gos. un-t», 1998. - S. 93.

21. Ivanov V.V. Obshchaya teoriya dogovorov. - M.: «Yurist"”, - 2006. - S. 238.

22. Korenev A.P., Abdurakhmanov A.A. Administrativnye dogovory: ponyatie i vidy // Zhurnal rossiiskogo prava. - 1998. - № 7. - S. 86.

23. Starilov Yu.N. Administrativnyi dogovor: opyt zakonodatel'nogo regulirovaniya v Germanii // Gosudarstvo i pravo. - 1996. - № 12. - S. 42-43.

24. Starilov Yu.N. Administrativnyi dogovor: opyt zakonodatel'nogo regulirovaniya v Germanii // Gosudarstvo i pravo. - 1996. - № 12. - S. 47.

25. Tsaliev A.M. Rasshirenie roli sub"'ektov Rossiiskoi Federatsii v gosudarstvennoi politike // NB: Voprosy prava i politiki.-2013.-3.-C. 21-94. URL: http://www.enotabene.ru/lr/article_554.html

26. But S.S. Sistema administrativno-pravovykh sredstv protivodeistviya korruptsii v tamozhennykh organakh Rossiiskoi Federatsii // NB: Administrativnoe pravo i praktika administrirovaniya.-2013.-9.-C. 88-98. URL: http://www.e-notabene.ru/al/article_10137.html

27. Arinin E.A. Teoreticheskie aspekty organizatsionno-pravovogo mekhanizma nalogooblozheniya v Rossiiskoi Federatsii. // NB: Finansovoe pravo i upravlenie.-2013.-4.-C. 1-29. URL: http://www.enotabene.ru/flc/article_855.html

28. Vasnetsova A.S. Patrioticheskoe vospitanie grazhdan Rossiiskoi Federatsii v sisteme protivodeistviya ekstremistskoi i terroristicheskoi deyatel'nosti:obshchefe deral'nye i regional'nye aspekty // NB: Natsional'naya bezopasnost'.-2013.-5.-C. 142-153. URL: http://www.enotabene.ru/nb/article_9517.html 